\title{
Interreligious Dialogue: From Coexistence To Proexistence \\ (Understanding The Views of Mukti Ali and Hans Kung)
}

Singgib Basuki*

\author{
Sunan Kalijaga State Islamic University, Yogyakarta, Indonesia
}

*Corresponding author: a.basuki@uin-suka.ac.id

\section{Article history}

Received: 2018-04-02 Received in revised form: 2018-08-13 Accepted: 2018-09-23 Published online: 2018-10-30

\begin{abstract}
The present and future worlds are pluralistic. Globalization has a direct effect on all aspects of human life, including religious patterns. The life of religious people in this global world should have a proper vision of their religion and other communities with a positive awareness of diversity. Each community should be aware of the existence of its own group and other groups with all the differences. Herein lies the importance of interreligious dialogue. Initially, the purpose of the interreligious dialogue is to foster pluralistic awareness of tolerance (co-existence) so that people can live together peacefully; however, the present and future dialogues must be actively involved in inter-religious cooperation programs (co-existence) to solve humanitarian problems. Among the initiators of the interfaith dialogue in the context of global life are Mukti Ali and Hans Kung. Although their intellectual and theological base is different, they both share a common vision, mission and a great agenda of interfaith dialogue in order to achieve a dynamic peace.
\end{abstract}

Keywords: Pluralistic, globalization, tolerance, cooperation program, Interreligius 


\subsection{INTRODUCTION}

The The plurality of religions in Indonesia is an inevitable history as well as the plurality of languages, ethnicities and cultures. The reality directly provides a valuable lesson for the nation of Indonesia in maintaining and managing inter-religious relations well. The centuries of experience in maintaining the inter-religious relationships to create an interfaith harmony make Indonesia a reference to other nations. One of the keys to Indonesia's success in maintaining good inter-religious relationships is the willingness of religious people to get involved in a dialogue.

Interfaith discourse and interfaith dialogue are getting stronger along with the crisis of modernity. According to Gilles Kepel, the paradigm of modernity has given rise to various paradoxes, chaos, and denials of human dignity. The crisis was responded by a religion that sought to present its ideal figure as a moral source, and as both a critic and a reformer. The idea has continued to roll out among the world's major religions such as Judaism, Christianity and Islam for nearly two decades as implied by Kepel: 'have succeeded in the' crisis of modernity 'into plants for re- building the world, and in their plants holy scripture provides the basis for tomorrow's society ' (Kepel, 1993).

In practice, the crisis of modernity that swept the world cannot be solved by religion alone or by other great world ideologies. Meanwhile, the contribution of the world's religions to guiding a modern, globalized and religious lifestyle of the future community must be constantly renewed and pursued continuously. The environmental problems, the impact of the use of sophisticated technology, the deeper the gap between rich and poor countries, the hegemony of the superpower against the weaker countries, and the increasing abuse of the rights of minority communities are parts of the global humanitarian problems which are becoming the common agenda of mankind transcending ideological and religious boundaries. To answer those problems, then, the need for the inter-faith dialogue arises.

Discussing the interfaith dialogue in the Indonesian context cannot be separated from Mukti Ali, as the initiator and the mobilizer of the dialogue. His obsession with comparative religion studies will foster interest for the interfaith dialogue and eliminate suspicion among religious people. In order to realize his desire, he academically opened the Comparative Religion Studies at the Faculty of Ushuluddin IAIN (State Islamic Institute) Sunan Kalijaga Yogyakarta in 1960. When he served as Minister of Religious Affairs of the Republic of Indonesia in 1971-1978, he intensively organized a series of interfaith dialogue program. What he does is in order to carry out the mandate to restructure and reorient the policies of the New Order government in order to create harmonious religious life in Indonesia (Ali Muhanif, 1989).

Entering the current global era, the contribution of all religions in solving humanitarian problems and challenges of the times in general is increasingly demanded, by joint hands together. However, there is a paradigm shift in interfaith dialogue that originally created interreligious harmony, which must now be seriously involved directly to solve global humanitarian problems. In this context, Hans Kung contributed the idea for interreligious dialogue by incorporating the element of humanity as a criterion of the truth of a religion Hans Kung, 1990). It should be further studied that the inter-religious dialogue is not only aimed at living together peacefully, harmoniously and tolerantly as the jargon of the New Order era by allowing believers of other religions to exist "(co-existence), but also actively participating in recognizing those believers (pro-existence). Thus, this paper aims to reveal the importance of dialogue between religions in the context of the global age, how much Mukti Ali and Hans Kung's contribution to Page | 68 
interreligious dialogue in their respective contexts and whether religions can work together to contribute their prophetic and theological values in addressing global humanitarian problems.

\subsection{KNOWING MUKTI ALI}

Mukti Ali was born on August 23, 1923 in Cepu, Blora, Central Java, and died on May 5, 2004 in Yogyakarta. He is known as an important figure in laying the foundation of the interfaith dialogue which is known to be very concerned about the creation of interfaith harmony in Indonesia. His attention to the importance of interfaith dialogue and tolerance cannot be separated from his expertise in the field of Comparative Religion. He is also known to have developed a scientific approach to religion called scientific-cum-doctrine (religious science) that combines a historical-sociological-anthropological-psychological approach with normative or doctrinaire. The knowledge, he obtained while studying at the Institute of Islamic Studies of McGill University, Montreal Canada (Ali Muhanif, 1989).

After returning to his homeland, Indonesia, he applied his knowledge through the academic world by teaching at PTAIN (State Islamic University of Yogyakarta) which later changed to IAIN Sunan Kalijaga Yogyakarta and IAIN Syarif Hidayatullah Jakarta. His academic achievement was gained by earning his title as Professor of Comparative Religion. With his capacity as an expert in Comparative Religion, he is often invited to speak in various national and international forums discussing the interfaith dialogue. He was also invited to give public lectures in non-Islamic high schools, delivering papers at scientific meetings on interfaith relations. On the basis of his expertise, he was appointed as Minister of Religious Affairs of the Republic of Indonesia in 1971-1978. At that time, the Indonesian people needed an expert who could parse and defuse inter-religious conflict that was tapering.

Between 1967 and 1970, there was a very harsh polemic between Islam and Christianity in the form of letters and pamphlets which were published both officially and unofficially. Both sides reproach to each other, for example Muslim authors deny the truth of Christian theological teachings and regard it as superstitious and illogical. Christian and Catholic, on the other hand, consider Islam's teachings as backward and fanatical. Another trigger of the tension between Islamic and Christian relations is the tremendous success that Christian missionaries achieved after 1965. In the early 1970s, the Muslim community was struck by the rapid growth of the Church in Central Java and East Java. Muslim figures charged that the government gave wind to the missionary activities. Most of those who convert to Christianity are "abangan" Muslims (mostly influenced by Javanese rituals in conducting their worship) and some are former PKI (Indonesian Communist Party) members who are mistreated by the "santri" (those who learn Islam in depth). This hostile attitude resulted in violent social conflict in the form of destruction of worship places, such as the burning of the Church by Muslim youths in Central Java and Aceh and the burning of mosques in Ambon by Christians (Wiliam n.d).

Not long after Mukti Ali was inaugurated as Minister of Religious Affairs, he devised a strategic program to reorder the interreligious relationships in order to foster tolerance and interreligious harmony. For him, tolerance and inter-religious harmony became very valuable and became the main prerequisite for the strengthening of social cohesion and national integration in order to succeed national development. To achieve his ideas, he organized a series of interfaith dialogue activities both in the Ministry of Religious Affairs of Jakarta and some areas in Indonesia. During his tenure as Minister of Religious Affairs, he succeeded in overhauling the Department's style of bureaucracy, image and mechanism of the Department of Religion from "ideology departments" into departments synchronized with "technocratic spirit". In addition, he also succeeded in incorporating religion in development, not legitimizing development by incorporating it in religion known as the "pembangunan manusia seutuhnya" / whole human 
development (Fauzi, 1995). With his various policies and works in the Ministry of Religious Affairs, Muslims are considered quite successful in playing an active role in the development.

Internationally, Mukti Ali is active in various interfaith dialogue forums such as:

1. The Ninth International Congress for the History of Religion, Tokyo 1958.

2. Dialogue between Men of Living Faiths, Beirut 1970.

3. World Conference on Religion and Peace, Kyoto 1970.

4. Christian Muslim Dialogue, Libanon, 1970.

5. Interreligious dialogue in Colombo, 1974

6. Christian-Muslim Encounter, Harford Seminary, 1990.

7. Joining the World Council of Churches for 25 years (Singgih Basuki, 2013).

After finishing his duty as Minister of Religious Affairs, he returned to his profession as a lecturer at IAIN Sunan Kalijaga Yogyakarta and wrote various articles and books. He conducted those activities diligently until the end of his life. His academic works are written in various themes: comparative religion, modern Islamic thought, education, national development, da'wah, culture and art, religious research methodology, sociology, law, economics and various translations.

\subsection{KNOWING HANS KUNG}

The Hans Kung was born on March 19, 1928, in Sursee, Switzerland. He was ordained a Roman Catholic Priest in 1954, and continued his theological studies at The Catholic Institute in Sorbonne, Paris, France. In the late 1960s, Kung became an important Roman Catholic theologian after the late 19th century Catholic Church that rejected the infallibility of the Pope in his book entitled "Infallible? An Inquiry". Because of his criticism of church dogmas and his demands for reformation in the church led to the lifting of the Catholic theological teaching permission by the Vatican. Nevertheless, he continued to teach as a Professor in Ecumenical Theology at the University of Tubingen until his retirement in 1996. Until now, he has been noted as a staunch critic of the Pope's authority which he considers to be a human creation, not something created by God. Kung is not excommunicated, and he remains a Roman Catholic priest (Martiam ed. n.d).

In 1980, he returned to teach at the University of Tubingen, and until now became Professor Emeretus at the University. In the early 1990s, he initiated the establishment of "Global Ethic Foundation" as well as inaugurated as its president. The project seeks to look for fundamental similarities held by religions rather than seeking differences that can be used as a common ethical foundation for all religious followers. The project also develops rules on minimum behavior acceptable to everyone. His vision of a Global Ethic is expressed in a document originally drafted by Kung: "Towards a Global Ethic: an Initial Declaration." The declaration was signed at a session of Parliament of World Religions in 1993 which was signed by many spiritual religious leaders from around the world. In its development, the project was transformed into an "Interfaith Dialogue" organized by the United Nations. Hans Kung was appointed to one of its leaders. However, since September 19, 2001, the project's existence dimmed (http://id.wikipedia.org/wiki/Hans Kung).

The work he produces is no less than 44 titles written in 22 languages as well as numerous articles submitted in various forums and contained in various journals. Among others are:

- On Being a Christian (1974)

- Signposts for the Future: Contemporary Issues facing the Church (1978)

- Does God Exist? An Answer For Today (1980)

- Christianity and the World Religions: Paths of Dialogue with Islam, Hinduism, and Buddhism (1986) Page $\mid 70$ 
- Why I am Still a Christian (1987)

- Christianity and Chinese Religions (1988)

- Theology for the Third Millennium: An Ecumenical View (1990)

- Global Responsibility: In Search of a New World Ethic (1991)

- Judaism: Between Yesterday and Tomorrow (1992)

- Christianity: Its Essence and History (1995)

- A Global Ethic for Global Politics and Economics (1997)

- $\quad$ The Catholic Church (2001)

- Women in Christianity (2001)

- Tracing the Way Spiritual Dimensions of the World Religions (2002)

- The Beginning af All Things: Science and Religion (2007)

- Islam: Past, Present and Future (2007) (Martiam (ed)

\subsection{INTERFAITH DIALOGUE ACCORDING TO MUKTI ALI}

The uniqueness of Mukti Ali in initiating the interreligious dialogue in order to create inter-religious harmony in Indonesia cannot be separated from his efforts in developing the Comparative Religion Sciences. Principles that he carries of "agree in disagreement" in assessing the religions scientifically, according to him, will facilitate the implementation of inter-religious dialogue. Through the dialogue, harmony of life among various religious communities will be formed. In addition, another goal of this science is that religious people can participate actively in the development and create a safe and peaceful world based on ethics and morals, not a world full of missile and nuclear threats (Mukti Ali 1988)..

Interfaith dialogue according to Mukti Ali is:

"Interfaith Dialogue is a meeting of hearts and minds between believers of various religions. Dialogue is communication between people who believe in the religious level. Dialogue is a common path to achieve truth and cooperation in projects of mutual interest. It is a religious encounter, without feeling low and without feeling high, and without an undisclosed agenda or purpose......... Interfaith dialogue is not an academic study of religion, nor it is to unite all religions into one, not an attempt to form a new religion that can be accepted by all parties, not arguing arguments between various religious groups until there is a win and some lose to be fruitful, demanding the participants of certain mental attitudes, such as respect, listening, sincerity, openness, and the willingness to accept and cooperate with others (Mukti Ali, 1999).

Meanwhile, the form of the interfaith dialogue is (Mukti Ali, 1999):

1. The Dialogue of Life, in which people of all religions and beliefs live together and make cooperation to enrich each other's beliefs without formal discussion. This dialogue went well in Indonesia which occurred in families, schools, armed forces, hospitals, industry, offices and the state. Here, the service and acceptance are done without distinction of religion.

2. Dialogue in Social Activities, aims to increase the integral value and liberation of mankind. Various religious followers work together in implementing development projects to improve family life, addressing the people who suffer from poverty and lack of food, helping refugees and promoting justice and peace.

3. The experience of Religion Communication Dialogue, is a dialogue in the form of communication of religious experience in the form of prayer, meditation, remembrance of God, fasting and the like for self-control, pilgrimage to holy places, contemplation and mysticism. For example Catholic and Buddhist ascetics hold certain dialogue by staying at other times for other hermits to gain experience and to learn about fasting, praying, reading scripture and so on. 
4. Dialogue for Joint Prayer, which is to pray together in meetings attended by various religious groups. Each group prays according to their own beliefs for the same purpose, that is peace. Each group is also present when other religious groups carry out the prayer.

5. Theological Discussion Dialogue, is conducted by religious experts to exchange information about beliefs and religious practices to seek mutual understanding between them.

As for the reasons why interreligious dialogue is necessary, there are two reasons: practical and theological. The practical reason is to understand the reality of the plurality of religions in the world, to better alter the judgments of other religions, to purify and deepen beliefs in religion, and to help promoting the interfaith cooperation in building a better life. As for the theological reasons: first, basically all mankind is a single community whose origin and purpose is God. Interfaith dialogue can help foster a universal awareness of the unity of mankind so as to encourage the promotion of universal peace. Secondly, through that awareness, all religions can take a positive attitude toward religion outside of their own religion. Through dialogue, interfaith cooperation can recognize, nurture and promote spiritual and moral actions (Mukti Ali, 1999).

Even so, in realizing the interfaith dialogue, according to Mukti Ali, it is not easy for many reasons, among them: the existence of terms that do not necessarily have a common meaning in all religions that can lead to misunderstandings; the emergence of suspicions of dialogue initiated by the Church because it is considered as a way of covert conversion; widespread concern that interreligious dialogue will lead to the emergence of syncretism, relativism and ignorance of religion; various streams or classes in every religion are not all willing to engage in dialogue, especially fundamentalist groups (Mukti Ali, 1999).

A series of interfaith dialogue activities to realize interfaith harmony on the initiative of Mukti Ali organized by the government through the Ministry of Religious Affairs in various places in Indonesia began intensively in the 1970s. In the 1980s a number of organizations and NGOs working in interfaith affairs also held dialogues, seminars, workshops, studies, book publications and courses. The form of dialogue that was carried out in this era focused more on theological, intellectual, and religious tradition themes than the social, environmental and humanitarian themes. Inter-religious dialogue in this era until the second half of the 1990s can be said to succeed based on the fact of the increasingly redundant issues of inter-religious disputes in the country. If there is a conflict between religions, people can already reduce it. The issuance of regulations on religious broadcasting as well as foreign aid to avoid tensions that lead to interreligious conflict. Similarly, the harmony ideology known as the "Trilogi Kerukunan/Harmony Trilogy" is accepted by all Indonesian people (Amin Abdullah, 1996).

Entering the third millennium and in line with contemporary developments, the world is undergoing a global revolution. Human life is in the early stages of forming a new society which is very different from the previous period. The global revolution was not built with a single ideology but with a variety of social, economic, technological, cultural and ethnic factors. Mankind is depicted in a terrible situation but at the same time contains a hopeful complexity. In dealing with the situation, mankind has the opportunity to develop new understanding and attitudes as a whole (Mukti Ali, 1997).

Facing this contemporary development, Mukti Ali expressed his views on dialogue that fits the global community situation. The dialogue that has been implemented to foster tolerance is no longer needed. According to him, humanity needs a dialogue that requires a joint movement of all religions to solve various humanitarian problems. In order to carry out intact religious 
dialogue, humanity must be able to overcome the many obstacles of dialogue that emerged over the past three decades:

1. There is concern for European Christians about the interfaith dialogue that when converting with another religion, one may signal a compromise with their own convictions. Meanwhile, Muslims already feel enough with the truth of their own religion so that it does not look important to dialogue with other religions.

2. The understanding of dialogue in the sense of talking to one another among Christians has been rooted in the ecumenical sense of Vatican II so that Pope VI emphasizes more dialogue with the Eastern Orthodox Church and other Christians. Dialogue in that sense can be misleading. According to him, the meaning of dialogue is "dia-leghe" that is talking or discussing about various issues to correct each other and move together to solve new problems. The same word is concourse which means running together, moving forward together, not just talking to a particular destination. The meaning also applies to relationships between the existing religions, not just the internal Christian Church.

3. The failure of Christians in their evangelistic efforts has encouraged them to communicate with other religions through dialogue. This issue raises the communication gap, triggering suspicion and questioning Christian sincerity in interfaith dialogue (Mukti Ali, 1997)..

It appears that the focus of interfaith dialogue put forward by Mukti Ali in facing the global era is more concentrated on interfaith cooperation in solving humanitarian problems. Thus there is a change in the meaning and purpose of interfaith dialogue that initially focused on fostering tolerance, openness and willingness to appreciate the differences in the teachings of religions in order to realize the harmony of life among religious people. In its development, in realizing the peace of mankind in the global era, it takes inter-religious cooperation to solve humanitarian problems.

\subsection{INTERRELIGIOUS DIALOGUE ACCORDING TO HANS KUNG}

Hans Kung points out the boundaries of interfaith dialogue in a very general form:

1. We can understand others seriously if we seek to understand the beliefs, values, rituals, and symbols of others.

2. We can truly understand our own faith including strengths and weaknesses, and constant and fluid facets if we seek to understand the beliefs of others.

3. We can find the same foundation of the various beliefs even if there is a usable difference to be the basis for peaceful coexistence in the world if we seek to understand the beliefs of others.

Thus, according to him, inter-religious dialogue requires an open attitude and not defensive, has the spirit to learn to each other with a humble attitude, and does not feel oneself as the most right one. Dialogue is essentially a critical function of religion (Hans Kung, 1998)..

To rediscover the credibility of religion and to find a firm foundation for honest and rigid religious dialogue, Hans Kung feels the need to clarify the concept of "religion" and how the religious criteria are correct. According to him, religion is difficult to define as art (Hans Kung, 1987). Religion is not to be defined much less debated but to be lived and enlivened in human beings. Religion is not a "thing" that is outside man but in man. When a follower of a religion meets with other believers, he/she must be prepared to admit and recognize a fundamental difference in terms of his/her view of the world, life, ways of doing and 
determining attitudes. If a person is said to hold a Hindu religion, then it means that he becomes a Hindu man, not just having a Hindu religion (Hans Kung, 1987). For him, religion is not simply related to theories or concepts but to life itself, the approach to life and the ways to live.

Hans Kung's view of the diversity of world religions consists of four possibilities: first, that none of the world religions is true. Secondly, there is only one true religion or all religions other than the religion are not true. Third, every religion is true or all religions are true. Fourth, there is only one true religion, with the understanding that all religions other than that religion take part in the truth of that one religion (Hans Kung, 1987).

Furthermore, Kung sets out several criteria for measuring how far a religion is properly categorized and good in terms of interfaith dialogue:

1. In the view of common ethics, a religion is said to be true and good if it is human, not oppressing and not destroying humanity but instead always protecting and appreciating human values.

2. According to religious criteria in general, a religion is said to be true and good if it always refers to the original source or theorem, to its original nature, scripture and character. The condition is continuous.

3. Particularly according to Christian criterion, a religion is said to be true and good if the religion in certain extent shows the spirit of Jesus Christ in its theory and practice (Martiam, ed).

Particularly the third criterion is the way in which Christianity views itself critically against Christianity. It also applies to other religions in viewing critically their respective religions.

As a theologian, Hans Kung offers a model of dialogical theology which he calls Ecumenical Theology. Theology is as a discipline that deals with the problem of faith and divinity, therefore Theology can only be understood by believers only. However, this knowledge should also be understood by those who aim to seek the truth even if they do not believe. He offers a model of dialogical theology similar to that of critical-ecumenical theology. Similarly, interreligious dialogue should require a model of theology that can be understood by all religions. For that, denominational theology should be transformed into Ecumenical Theology (Hans Kung, 1982). The world at large according to Hans Kung desperately needs three things that actually exist in ecumenism:

1. Theology that corresponds to the dialogue. The suitable theology is Ecumenical Theology. Ecumenical theology is not an individual but a common-interest oriented that is not limited only to the abstract field but to the particular things of thought and life.

2. Theology to be changed. Hans Kung from the beginning has changed the purpose, influence and vision of Ecumenical Theology. What it does is as a service to the Church, to fellow human beings and to build humanity in the future. Ecumenism must be more advanced and the Church must change itself in new times. Its attention should be focused on the world's religions and its responsibility to the world must be demonstrated in a concrete form.

3. Theology is responsible for peace. To that end, Ecumenical Theology seeks to lay its responsibility for universal peace and harmony (Hans Kung, 1998)..

The purpose of ecumenism for Kung is to provide a critical response to the tendencies of absolutism, exclusivism, syncretism and other extreme tendencies that are considered as a form of religious deviation. Ecumenism is also to remove the superior attitude of the Church and the Christian monopoly of truth (Martiam ed.).

Furthermore, assuming that the world and religion have changed, the world has become polycentric, multi-cultural and multi religious unity; geographical and religious boundaries have 
become pseudo that inevitable interrelationship and influence between religion and other aspects of life occurred. In such conditions, religion must be able to get involved to solve the challenges of the times in general as well as humanitarian problems globally. In that context, Hans Kung proposed a "global ethic". According to him, every religion has its own teachings that differ from one another but the ethics and behavior of religions have many similarities (Hans Kung, 1990).

Hans Kung's view of the true and good criteria of a religion determined by the extent to which a religion is capable of solving humanitarian problems, global ethics and Ecumenical Theology as stated above, contributes much to the interreligious dialogue. Hans Kung realized that inter-religious dialogue is not merely aimed at living together peacefully, harmoniously and tolerantly by allowing other religions or co-existence as it has been developed, but also actively participating in solving the humanitarian problem of other religious followers or pro-existence (Komaruddin, 1998). Through pro-existence, it is hoped that the target of dialogue can feel more authentically involved and planned.

With the paradigm shift in interfaith dialogue, Kung does not intend to underestimate tolerance as a minimal prerequisite for peaceful co-existence. The dialogue of the pro-existence model is not merely an attempt to collect the elements of conflict that can lead to conflict but to recognize other religions without prejudice as well as to know the religion itself more critically through the religions of others. This effort will succeed if supported by the emergence of ecumenical awareness globally (Hans Kung, 1987). What Hans Kung proposes is the answer to the challenge of interfaith dialogue in a globalized era that puts the human dimension rather than the theological aspect.

\subsection{THE PARADIGM SHIFT OF CONFLICT-PEACE AND THE CHALLENGE OF DIALOGUE}

Along with the development and demands of modern society, there is a change of meaning towards peace. To make it happen, there are two theories: classical and modern:

1. The classical and conservative view of conflict resolution that is considered legitimate and rational in order to realize peace is that violence can only be paralyzed by violence. The adherents of this theory stem from the view of Roman historian Titus Livius with the expression of si vis pacem, para bellum (if you want peace, prepare for war). This theory necessitates the view that a calm and peaceful atmosphere will be created if the source of violence has been eliminated. Peace is interpreted as a situation without violence, conflict, hostility and so on. This is what is called "Passive Peace".

2. The modern worldview asserts that peace is not simply interpreted as a situation without conflict with violence. Peace in the modern context is a dynamic, social, constructive, humanist, civilized society as a means of salvation without distinction of ethnicity, religion, nationality or social class. This is called "Active Peace" (Baowolloi, 2010).

This shift in the peace-conflict paradigm emerged fundamentally after World War I, II and the Cold War. Future conflicts according to the UN are not solely due to state security issues but more due to human security factors that include fulfilling the basic needs of human life. In other words, injustice in the form of neglect of basic human rights and necessities will trigger conflict and it will be difficult to realize peace in the life of a society. This shift in the paradigm of peace centered on this human factor has implications for the purpose and pattern of the interfaith dialogue. If the interfaith dialogue that lasted for three decades ago focused more on fostering tolerance and respect for the existence of different religions, then in the future it must be oriented to solve humanitarian problems together according to the sacred message of each religion. In that way, the expected active peace will be realized.

Page $\mid 75$ 


\subsection{THE INTERSECTION BETWEEN MUKTI ALI AND HANS KUNG}

In order to answer the question of the extent to which religion is involved in solving humanitarian problems globally and the challenges of the times in general, both Mukti Ali and Hans Kung are committed to making it happen but each has a different outlook. Yet the basis of both views is the same, i.e. the interfaith dialogue. Both seek to make the holy message of religion to achieve lasting peace or an active peace in the order of life of the people to be achieved. Mukti Ali states that in the context of global religious encounter, mankind does not simply need interreligious dialogue in the sense of intellectual and theological conversations between religions, but more than that, it is necessary to move together to achieve the goal of humanity thoroughly (Mukti Ali, 1997).

In order to create peace in the era of global society, Mukti Ali proposes a new orientation in the meeting of religions, including on the interfaith dialogue. If in the past three decades the focus of the interfaith dialogue is to understand and to communicate, then in the global era, he proposed three important points of the interfaith dialogue in which the focus is on the interfaith cooperation:

1. In the framework of the unity of mankind, it is necessary to establish a Union of Religions such as the Council of Global Religions in addition to the United Nations. In such institutions, religions can dialogue to realize and maintain the peace of mankind which emphasizes three conditions namely: justice; local, regional and international peace; and an environment that can improve local and global living standards.

2. In order to overcome the influence of secular life, it is necessary to increase the transcendental dimension of human life. Interreligious societies should not be solely "an sich" political, social, economic and cultural orientations but must base on them transcendently. In order to increase the human dignity, the transcendental or divine dimension must be transformed into institutional and cultural forms.

3. All religions assume that religious dogmas and doctrines are important but in fact spiritual or moral discipline is more important. To understand and practice the moral discipline of one's religion, he/she must seek to understand the moral discipline of other religions. The understanding and appreciation of the spiritual and moral disciplines of other religions that are not only on the intellectual dimension will encourage the realization of meetings of religions. Furthermore, through the inter-religious dialogue, it will be established point of contact, cooperation, mutual trust and the emergence of new forms of humanity (Mukti Ali, 1997).

Mukti Ali's view indicates that in order to realize a peaceful, safe and comfortable life in a global society, the form of inter-religious dialogue is not merely exchanging ideas, resulting in a tolerant attitude, but it is the dialogue in a more concrete form that is the justice of every society, local and international peace and an environment that promotes life locally and globally. For that, it takes inter-religious cooperation in overcoming humanitarian problems. He is very concerned about the order of life of a world of peace, justice and humanity. In other words, if the three conditions are met then the people will live in peace. This is peace in an active sense, not a passive one.

Meanwhile, Hans Kung is known as a theologian who idealized a world order of peace and tranquility, free from conflict and violence. With a view based on Ecumenical Theology, he proposes a global ethos that supports the peaceful coexistence of all humanity in a common home. He proposed a well-known peace trilogy: "there is no survival of mankind without a global ethos, no world peace without peace among religions, no peace between religions without the interfaith dialogue" (Hans Kung, 1999). The phrase implies an appeal to all religions to start a Page | 76 
new phase of building a world peace based on a shared ethos that emanates from the spiritual values of every religion.

The purpose of the interreligious dialogue is not merely the realization of tolerance as a condition of peace in the passive sense which he calls "co-existence", but furthermore is active peace or "pro-existence". With the expected pro-existence, the intercultural dialogue goals can be more involved and programmatic by involving authentic differences. That way, the main purpose of the dialogue to realize tolerance or co-existence phase is over. Nevertheless, tolerance is still regarded as the most important condition but not enough to bring peace to the global community. Religious people, especially Christians, according to Hans Kung, should get out of the isolation shell and learn to understand the reality of other religions. After the period of physical war, cold war, and ceasefire, the world is now in a period of "pro-existence" characterized by the rise of global ecumenism of consciousness.

Thus, these two figures hold the same view that the main goal of the interreligious dialogue in the global era is the realization of an active peace, a dynamic and constructive situation. A situation in a society where there is a dynamic social, constructive, humanist, and civilized relationship as a vehicle of salvation for all mankind without distinguishing tribe, religion, nation and social status. In other words, both Mukti Ali and Hans Kung place the human factor as the center of the discourse of peace building which is the holy mission of all religions. To make it happen, dialogue needs to be in a concrete form of inter-religious cooperation, not merely acknowledging another existence (co-existence) but willing to cooperate (pro-existence).

\section{References}

Ali Munhanif. (1989). Prof. Dr. H.A. Mukti Ali: Modernisasi Politik Keagamaan Orde Baru. Menteri-menteri Agama: Biografi Sosial Politik. Jakarta, PPIM.

Amin Abdullah. (1996). Anatomi Kerukunan Umat Beragama: Tinjauan Historis-Sosiologis. (Paper). Yogyakarta: Indonesia.

Avery T. William. (n.d.). Indonesian Revival: Why Two Million Came to Christ. South Pasadena, William Carey.

B.J. Boland. (1985). Pergumulan Islam di Indonesia. Jakarta, Grafiti Press.

Gilles Kepel. (1993). The Revenge of God: The Resurgence of Islam, Christianity and Judaism in Modern World. Pensylvania, The Pensylvania State University Press.

Hans Kung. (1987). Christianity and The World Religions: Paths of Dialogue with Islam, Hinduism, and Buddhism. Evantons, Northwestern University Press.

Hans Kung. (1990). Towards a World Ethics of World Religions. CONCILIUM 2.

Hans Kung. (1998). Sebuah Model Dialog Islam-Kristen. Jurnal Paramadina. Vol.1 No.1. Juli-Desember.

Hans Kung. (1999).Project Weltethos. Pieper Verlag GmBH. Munchen. 5 Auflage.

http://id.wikipedia.org/wiki/Hans Kung, accessed on October 18, 2017.

Komaruddin Hidayat and Ahmad Gaus AF (eds). (1998). Passing Over: Melintas Batas Agama. Jakarta, Gramedia Pustaka Utama and Gramedia.

Mukti Ali. (1970). Dialog Antar Agama. Yogyakarta, Nida.

Mukti Ali. (1988). Ilmu Perbandingan Agama di Indonesia. Yogyakarta, IAIN Sunan Kalijaga Press.

Mukti Ali. (1990). Ilmu Perbandingan Agama dan Kerukunan Hidup Antar Umat Beragama. 70 Tahun Dr. T.B. Simatupang: Saya adalah orang yang Berbutang. Jakarta, Pustaka Sinar Harapan. 
Singgih Basuki / UMRAN - International Journal of Islamic and Civilizational Studies. vol. 5, no.2-1 (2018) pp. 67 - 78

Mukti Ali. (1992). Ilmu Perbandingan Agama, Dialog, Dakwah dan Missi. Ilmu Perbandingan Agama di Indonesia dan Belanda. Jakarta, INIS.

Mukti Ali. (1997). Agama, Moralitas dan Perkembangan Kontemporer. Agama dalam Pergumulan Masyarakat Kontemporer. Yogyakarta, Tiara Wacana.

Najiyah Martiam (ed). (n.d.). Jalan Dialog Hans Kung dalam Perspektif Muslim. Yogyakarta, CRCS cooperates with ICRS, ICIP, Swiss Embassy and Mizan.

Nasrullah Ali Fauzi. (1995). Abdul Mukti Ali. Ulumul Qur'an. No.3 Vol.VI.

Robert B. Baowollo. (2010). Menggugat Tanggung Jawab Agama-agama Abrahamik bagi Perdamaian Dunia. Yogyakarta, Kanisius.

Singgih Basuki. (2013). Pemikiran Keagamaan Mukti Ali. Yogyakarta, UIN SUKA Press. 